\title{
Effect of Nutrient Management on Growth, Yield and Yield Attributes of Rice (Oryza sativa L.)
}

\author{
Papia Biswas $^{1 *}$, Jitendra Singh Bohra ${ }^{1}$ and Nitesh Kumar ${ }^{2}$
}

${ }^{1}$ Department of Agronomy, Institute of Agricultural Sciences, Banaras Hindu University, Varanasi-22100, India

${ }^{2}$ Department of Genetics \& Plant Breeding, Faculty of Agriculture, Bidhan Chandra Krishi Viswavidyalaya, Mohanpur-741252, India

*Corresponding author

\section{A B S T R A C T}

\section{Keywords}

Inorganic fertilizers, Integrated nutrient management, RDF, Rice, Yield

\section{Article Info}

Accepted:

25 February 2020

Available Online:

10 March 2020
The present experiment was conducted at the Agricultural Research Farm, Institute of Agricultural Sciences, B.H.U., Varanasi, India during rainy (Kharif) season, 2012 to evaluate the effect of inorganic fertilizers and integrated nutrient management practices on the growth and yield of rice variety HUR-105 (P9). The experimental plants were grown under a randomized block design replicated thrice with 7 treatments. Combined application of $100 \% \mathrm{RDF}+\mathrm{S}_{40} \mathrm{Zn}_{5} \mathrm{~B}_{1.5} \mathrm{~kg}^{-1}$ significantly increased the growth parameters such as plant height, number of tiller hill ${ }^{-1}$, number of green leaf hill ${ }^{-1}$ and shoot dry weight hill ${ }^{-1}$. The next best treatments with respect to growth parameters were $100 \% \mathrm{RDF}$ and $312 \mathrm{~kg}$ customized fertilizer $+85.7 \mathrm{~kg} \mathrm{~N}$ through urea. Leaf chlorophyll content (SPAD) value was found to be highest with the application of $312 \mathrm{~kg}$ customized fertilizer $+85.7 \mathrm{~kg} \mathrm{~N}$ through urea closely followed by $100 \% \mathrm{RDF}+\mathrm{S}_{40} \mathrm{Zn}_{5} \mathrm{~B}_{1.5} \mathrm{~kg} \mathrm{ha}^{-1}$. The yield and yield attributing characters were also higher under the combined application of $100 \% \mathrm{RDF}+\mathrm{S}_{40} \mathrm{Zn}_{5} \mathrm{~B}_{1.5} \mathrm{~kg} \mathrm{ha}^{-1}$. Application of $100 \% \mathrm{RDF}+\mathrm{S}_{40} \mathrm{Zn}_{5} \mathrm{~B}_{1.5} \mathrm{~kg}$ ha ${ }^{1}$ markedly enhanced the gross return (Rs $84003 \mathrm{ha}^{-1}$ ), net return (Rs $54448 \mathrm{ha}^{-1}$ ) and being at par with other treatments recorded significantly higher gross as well as net return than control and $75 \% \mathrm{RDF}+25 \% \mathrm{~N}$ through vermicompost.

\section{Introduction}

Rice (Oryza sativa L.) is the member of family Poaceae. The productivity of rice depends on the successful completion of the crop growth range and the effective developmental activities for individual plants, which exploits the full genetic potential of the cultivar, which is well integrated with the environmental conditions. However, the role of balanced nutrition is recognized as the most important single factor to realize the maximum yield of rice. The effective role of nutrients in improving the quality of the product, along with the plant's autogeny and crop yields, are well recognized. Various cost-effective agricultural and nutrient management practices are thus the most 
important factors for success and sustainability of rice production.

During the Green Revolution era in the 1960s, production increased as a result of an increase in both rice-wheat area and system productivity. But now there is little additional land available and traditional farming is rapidly being lost to urbanization. Therefore, future demand for food will have to be met primarily through increased production per unit of harvested area (Ladha et al., 2000). The indiscriminate use of inorganic fertilizers and plant protection chemicals to increase crop yields led to an imbalance in the ratio of $\mathrm{N}$ : P: K of fertilizers which resulted in the deterioration of physical, chemical and biological health of rice-wheat growing soils. Currently, there is growing concern about the sustainability of the rice-wheat cropping system as the growth rate of rice and wheat yields is stagnant or declining in many states like Punjab, Haryana, Eastern Uttar Pradesh, Madhya Pradesh, Bihar, Himachal Pradesh and Jammu and Kashmir (Ladha et al., 2000; Mahajan and Gupta, 2009). Integrated nutrient management (INM) is one of the most appropriate and adaptable practices in which both organic and inorganic sources of nutrients are incorporated to increase crop yields without decreasing soil fertility. It has been established through integrated nutrient management experiments that combining organic sources viz. biofertilizers, farm manure, crop residues, green manure with the chemical fertilizers lead to efficient crop growth and improves soil organic carbon content and thus the gap between potential and actual yield can be sustainably bridged.

\section{Materials and Methods}

The present investigation involved a field experiment conducted at Agricultural Research Farm, Institute of Agricultural Sciences of Banaras Hindu University located at Varanasi, India during rainy season of 2012, followed by laboratory analyses of the plant grain, straw as well as soil samples during 2013. The experimental area had uniform well-drained topography with an assured source of water supply. The soil of experimental site was Gangetic alluvial having sandy clay loam texture with $p \mathrm{H}$ 7.95. Experimental soil was moderate in fertility with organic carbon of 0.41 ranging between $0.455 \%$ to $0.565 \%$ and available nitrogen content being $138.48 \mathrm{~kg} \mathrm{ha}^{-1}$, available phosphorus (23.48 kg ha-1) and available potassium $\left(139.10 \mathrm{~kg} \mathrm{ha}^{-1}\right)$ in soil were moderate. The present experiment was conducted on the rice variety HUR-105 (P9). This variety was developed from Banaras Hindu University, Varanasi, UP in the year 2009. This is a mutant of variety MPR 7-2 semi-dwarf in nature $(100-102 \mathrm{~cm})$. It takes 130-135 days for maturity. This is a neck and leaf blast tolerant variety with long slender grains yielding 50-55 q/ha. The experiment was laid out in a randomized block design with 7 treatments of inorganic fertilizers and integrated nutrient management (control $\mathrm{N}_{0} \mathrm{P}_{0}$ $\mathrm{K}_{0}, 100 \% \mathrm{RDF}, 100 \% \mathrm{RDF}+\mathrm{S}_{40}+\mathrm{Zn}_{5}+\mathrm{B}_{1.5}$, Customized fertilizer, $75 \% \mathrm{RDF}+25 \% \mathrm{~N}$ through Sewage Sludge, $75 \%$ RDF $+25 \% \mathrm{~N}$ through Vermicompost, $75 \% \mathrm{RDF}+25 \% \mathrm{~N}$ through Sesbania green manuring) replicated thrice. To study the effect of treatment, observations were recorded during the course of investigation on various parameters viz. growth characters, yields attributes and yield. Growth parameters were recorded at various phenological stages starting from 30 DAT followed by 60, 90 DAT and at harvest which included plant height, number of tiller hill ${ }^{-1}$, number of green leaf hill ${ }^{-1}$, leaf chlorophyll content and shoot dry matter hill ${ }^{-1}$. Similarly, number of yield attributes like panicle length, grain panicle ${ }^{-1}$,test weight, grain yield and straw yield and total uptake of the nutrients were also noted to assess the effect of treatments. 
Half of the nitrogen along with the full dose of phosphorus, potassium, zinc, sulphur and boron were applied through urea, diammonium phosphate (DAP), muriate of potash, zinc sulphate and borax respectively just before transplanting on puddled surface and incorporated into the top $15 \mathrm{~cm}$ soil manually. In treatments $\mathrm{T}_{2}$ To $\mathrm{T} 7$, the remaining half $\mathrm{N}$ applied through urea in two equal splits, instalments at critical tillering and panicle initiation stages. The total rainfall received during the crop period was 663.1 $\mathrm{mm}$. The maximum and minimum temperatures were $34.3^{\circ} \mathrm{C}$ and $11.4^{\circ} \mathrm{C}$, respectively.

The data collected during the course of experimentation were subjected to statistical analysis to draw valid conclusion. Finally, the different treatments were assessed for their gross return, net return and benefit: cost ratio. Standard field techniques, methods of observation, analysis of soil and plant samples and appropriate statistical methods for analyses of the data were used. The economics of various treatments were worked out separately by considering the existing price of inputs and produce. The investment in fertilizers, labour, and power for performing different operations such as ploughing, weeding, irrigation, harvesting, threshing, and winnowing, etc. were worked out $\left(\mathrm{ha}^{-1}\right)$ as per rate prevalent at the Agricultural Research Farm, Institute of Agricultural Sciences, B.H.U., Varanasi. The cost of cultivation was considered for calculating economics of treatments and expressed as the net return ( $\left.\mathrm{ha}^{-1}\right)$ and output: input ratio. The yield of the rice crop was converted into gross income in per hectare based on the current price of the grain and straw. The net return was worked out by using the following formula:

Net return ('Rs. ha ${ }^{-1}$ ) = Gross income ('Rs. $\mathrm{ha}^{-1}$ ) - cost of cultivation ( Rs. ha ${ }^{-1}$ )
The output: input ratio was worked out on the basis of net return per unit cost of cultivation (Rs. ha ${ }^{-1}$ ).

Benefit: cost ratio $=$ Gross income $\left(\right.$ Rs. $\left.\mathrm{ha}^{-1}\right)$ : Cost of cultivation ( Rs. ha ${ }^{-1}$ )

\section{Results and Discussion}

The weather condition during the crop season is one of the most important factors which determine the extent of crop growth, development, and overall performance. A slight deviation from the normal range in weather conditions may adversely affect crop growth and ultimately the yield. However, rainfall condition was not very satisfactory as total rainfall received during the growing period was $663.1 \mathrm{~mm}$. Whenever moisture stress occurred irrigation was provided to check the moisture stress. As such the weather conditions were satisfactory which favoured proper growth and development and finally the good yield of rice.

\section{Effect on growth}

The effect of fertility levels was noticed on various growth parameters viz. plant height, tillers hill $^{-1}$, green leaves hill ${ }^{-1}$, leaf chlorophyll content and dry matter accumulation hill ${ }^{-1}$ (Table 1 and Table 2). As compared to control, the application of nutrients through inorganic fertilizers (T2, T3, T4) and INM treatments (T5, T6, T7) improved all the growth parameters. Application of $100 \% \mathrm{RDF}+\mathrm{S}_{40} \mathrm{Zn}_{5} \mathrm{~B}_{1.5} \mathrm{ha}^{-1}$ was found significantly superior to $100 \%$ RDF, $75 \%$ RDF $+25 \% \mathrm{~N}$ through Sludge, $75 \% \mathrm{RDF}+25 \% \mathrm{~N}$ through Vermicompost and $75 \% \mathrm{RDF}+25 \% \mathrm{~N}$ through Sesbania and control at almost all the stages in respect of plant height, tillers hill ${ }^{-1}$, green leaves hill ${ }^{-1}$, leaf chlorophyll content and dry matter accumulation hill ${ }^{-1}$. However, with respect to green leaves hill $^{-1}$ at 30 DAT, $312 \mathrm{~kg}$ 
customized fertilizers $+85.7 \mathrm{~kg} \mathrm{~N}$ through urea performed better.

With the adequate nutrient application, the nutrient supplying capacity of soil to plants increases. The stimulated growth under adequate supply of nutrients is a well-known fact. Inadequate availability of nutrients in control plot resulted in poor growth and performance of crop. The significant increase in plant height was recorded with the application through different inorganic and INM treatments (Table 1). In T3 the highest plant height was recorded at every growth stage over other treatment in rice. The increase in plant height may be due to the adequate supply of major as well as secondary micronutrients. (S, Zn, and B) through chemical fertilizers. Nitrogen being constituent of protein, chlorophyll and that of phosphorus of nucleic acid, phytin and phospholipids, when supplied in adequate amounts, are expected to favor the production of protein to the maximum extent resulting into vigorous plant growth. The extra protein allows the plants to grow faster. Thus, plants supplied with adequate amount of major nutrients (T2, T3, T4) produced more leaves and brought about greater accumulation of photosynthates, yielding more height, no. of tiller hill ${ }^{-1}$ and shoot dry weight. These findings are in close agreement with those of Maqsood et al., (2005) and Manzoor et al., (2006). Phosphorus application has been reported to promote rice growth by Guo (2002), Hussainiet al., (2005) and Watanabe et al., (2007). Unlike nitrogen and phosphorus, potassium though does not form an integral part of plant constituents but showed an effective influence on all the growth parameters. This is in close agreement with the earlier findings of Singh et al., (2000) and Kumar et al., (2005).

The tiller production was markedly better in $\mathrm{T} 3\left(100 \% \mathrm{RDF}+\mathrm{S}_{40} \mathrm{Zn}_{5} \mathrm{~B}_{1.5} \mathrm{~kg} \mathrm{ha}^{-1}\right)$ than other treatments at all the growth stages (Table 1). This could be attributed to the adequate availability of secondary and micronutrients along with the major nutrient. Rahman et al., (2008) also reported that the effective tillers increased due to the application of $\mathrm{S}$ and $\mathrm{Zn}$ used at the recommended rate $\left(20 \mathrm{~kg} \mathrm{~S}\right.$ and $\left.3 \mathrm{~kg} \mathrm{Zn} \mathrm{ha}{ }^{-1}\right)$. Similar views have been expressed by Islam et al., (1996) for Sulphur application and by Tejasarwana (1991) for the application of zinc. The numbers of green leaves hill $^{-1}$ were found higher comparatively in T4 at 30 DAS (Table 2). However, at 60 and 90 DAT maximum number of green leaf hill $^{-1}$ were found associated with treatment T3 which was $29 \%$ and $35 \%$ higher, respectively over control. This could be ascribed to the production of taller plants and enhanced tillering in $\mathrm{T} 3$ due to better availability of secondary and micronutrients $(\mathrm{S}, \mathrm{Zn}, \mathrm{B})$ accompanied by an adequate supply of NPK. The greater production of leaves hill ${ }^{-1}$ and chlorophyll content as evident from SPAD values (Table 2). The dry matter production hill $^{-1}$ increased progressively till the harvest stage, irrespective of treatments. Different sources and levels of treatments resulted in significant variation in dry matter production hill $^{-1}$ at all days of observation. The highest dry matter production hill ${ }^{-1}$ was recorded under $100 \%$ RDF along with $\mathrm{S}, \mathrm{Zn}, \mathrm{B}\left(\mathrm{T}_{3}\right)$ and being at par with $T_{2}$ and $T_{4}$ proved significantly superior to other treatments. Nevertheless, the lowest shoot dry weight was recorded under control $\left(\mathrm{T}_{1}\right)$. Treatments $\mathrm{T}_{5}, \mathrm{~T}_{6}, \mathrm{~T}_{7}$ are at par with each other in all the observation days. The lowest shoot dry weight hill ${ }^{-1}$ was recorded in control throughout the growth period. T3 might have resulted in greater photosynthetic activities and accumulation of dry matter in the plants. Similar findings were reported by Sudhkar et al., (2006). Several workers have reported better growth responses of rice to integrated nutrient management (Babu et al., 2000, 
Jeyabal and Kuppuswamy, 2001). However, in the present investigation, $25 \% \mathrm{~N}$ substituted through sewage sludge (T5), Vermicompost (T6) and Sesbania green leaf manuring (T7) did not as good as $100 \%$ RDF $+\mathrm{S}_{40} \mathrm{Zn}_{5} \mathrm{~B}_{1.5}(\mathrm{~T} 3)$. This could be attributed to the slower rate of mineralization of these organic sources as well as this was the first year of the experimentation, so the build-up of organic matter in soil would not have taken place.

\section{Effect on yield and yield attributes}

It is obvious from the data that the various inorganic and INM fertility treatments markedly influenced the yield attributing characters of rice (Table 3). Application of $100 \% \mathrm{RDF}+\mathrm{S}_{40} \mathrm{Zn}_{5} \mathrm{~B}_{1.5}$ (T3) recorded significantly longer panicle than other treatments. Treatments T2, T3, T4, T5, and T6 though remained at par with each other produced significantly longer panicle than control (T1). The results showed that application of $100 \% \mathrm{RDF}+\mathrm{S}_{40} \mathrm{Zn}_{5}$ $\mathrm{B}_{1.5}$ helped in increasing ear length which could be attributed to the adequate availability of major, secondary and micronutrients to the plant. The present study is in partial agreement with the results reported by Abbas et al., (2013). The increase in number of grain panicle $^{-1}$ may also be the result of improvement in the soil fertility due to application of optimum level of NPK accompanied with $\mathrm{S}_{40} \mathrm{Zn}_{5} \mathrm{~B}_{1.5}$ ha $^{-1}$ under T3 where, good plant growth might have resulted into better translocation of photosynthates to the sink that led to better seed setting and the production of more number seed panicle ${ }^{-1}$ with higher test weight. Islam et al., (1996) reported a significant increase in the number of grains panicle ${ }^{-1}$ of rice variety BR11 at farmer's field in Melandha by the incorporation of $20 \mathrm{~kg} \mathrm{~S}$ and $5 \mathrm{~kg} \mathrm{Zn} \mathrm{ha}{ }^{-1}$ coupled with NPK.
Grain yield is the function of all the yield attributing characters contributing their share in different proportions. Whereas, the performance of yield attributes is directly correlated with growth performance. Grain yield is found to be increased with the application of $100 \% \mathrm{RDF}+\mathrm{S}_{40} \mathrm{Zn}_{5} \mathrm{~B}_{1.5} \mathrm{~kg}$ ha ${ }^{1}$ integrated. Correlation studies have shown that grain yield is highly correlated with the number of effective tillers, the number of grains per panicle and test weight of 1000 grain. A similar result was reported by Sudhakar et al., (2006) and Abbas et al., (2013). Straw yield increased significantly with fertilizer application. The straw yield of a crop is closely related to vegetative growth viz. plant height, leaves, number of tillers, etc. An increase in the chlorophyll concentration in leaf thus increases the photosynthesis rate and ultimately photosynthetic products so increased dry weight of plants. Application of $75 \% \mathrm{RDF}+25 \% \mathrm{~N}$ through sewage sludge being at par with $100 \% \mathrm{RDF}+\mathrm{S}_{40} \mathrm{Zn}_{5} \mathrm{~B}_{1.5} \mathrm{~kg}$ $\mathrm{ha}^{-1}$ produced significantly higher straw yield than rest of the treatments. This might be due to the availability of all essential elements to the rice crop in sufficient amount under these treatments. Similar results were reported by Jamil et al., (2004) and Abbas et al., (2013).

\section{Comparative economics}

Different fertility treatments caused markedly variation in the cost of cultivation. Differences were large in INM treatments. Due to the high cost of Vermicompost, T6 had maximum cultivation cost (Rs. 36,611 $\mathrm{ha}^{-1}$ ) followed by T7 (Rs. 32,716 $\mathrm{ha}^{-1}$ ) where $25 \% \mathrm{~N}$ was substituted through Sesbania (Table 4). However, due to its lower price, treatments involving sewage sludge recorded lowest cost of cultivation among all the treatments supplying nutrients. Treatments involving customized fertilizer (T4) due to its higher price recorded higher cultivation cost than $100 \% \mathrm{RDF}(\mathrm{T} 2)$ and $100 \% \mathrm{RDF}+\mathrm{S}_{40}$ $\mathrm{Zn}_{5} \mathrm{~B}_{1.5} \mathrm{~kg} \mathrm{ha}^{-1}(\mathrm{~T} 3)$. 
Table.1 Effect of treatments on plant height and tillers per hill

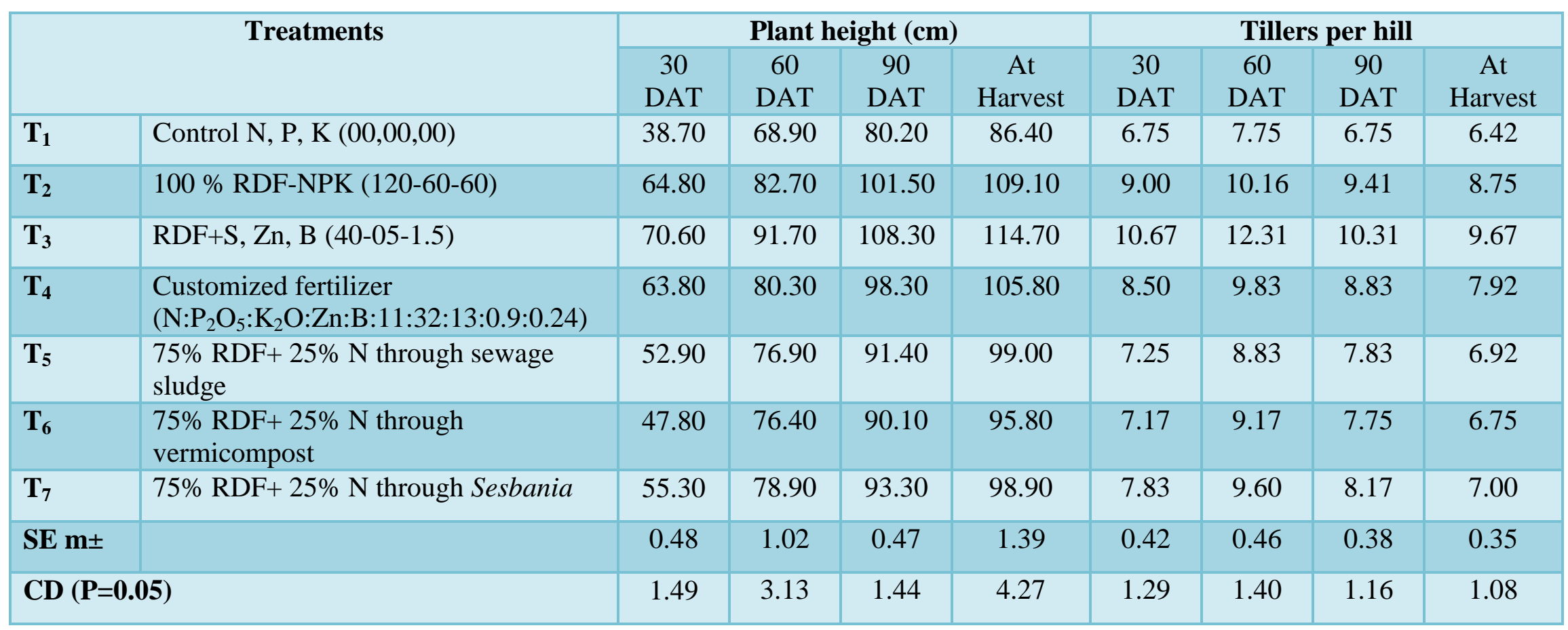


Table.2 Effect of treatments on green leaves per hill, shoot dry weight and chlorophyll content

\begin{tabular}{|c|c|c|c|c|c|c|c|c|c|c|}
\hline \multirow{2}{*}{\multicolumn{2}{|c|}{ Treatments }} & \multicolumn{3}{|c|}{$\begin{array}{l}\text { Green leaves } \\
\text { per hill }\end{array}$} & \multicolumn{4}{|c|}{$\begin{array}{l}\text { Shoot dry weight } \\
\text { (g hill-1) }\end{array}$} & \multicolumn{2}{|c|}{$\begin{array}{l}\text { Chlorophyll Content } \\
\text { (SPAD Value) }\end{array}$} \\
\hline & & $30 \mathrm{DAT}$ & $60 \mathrm{DAT}$ & 90 DAT & $30 \mathrm{DAT}$ & $60 \mathrm{DAT}$ & $90 \mathrm{DAT}$ & At Harvest & $60 \mathrm{DAT}$ & $90 \mathrm{DAT}$ \\
\hline $\mathbf{T}_{1}$ & Control N, P, K $(00,00,00)$ & 22.30 & 27.10 & 23.80 & 3.23 & 8.1 & 17.34 & 27.96 & 20.30 & 29.40 \\
\hline $\mathbf{T}_{\mathbf{2}}$ & $100 \%$ RDF-NPK (120-60-60) & 26.70 & 34.20 & 32.10 & 6.2 & 17.87 & 36.53 & 55.13 & 28.40 & 36.70 \\
\hline $\mathbf{T}_{\mathbf{3}}$ & $\mathrm{RDF}+\mathrm{S}, \mathrm{Zn}, \mathrm{B}(40-05-1.5)$ & 28.70 & 38.00 & 36.80 & 7.27 & 19.14 & 40.2 & 58.53 & 29.90 & 37.80 \\
\hline $\mathbf{T}_{4}$ & $\begin{array}{l}\text { Customized fertilizer } \\
\left(\mathrm{N}: \mathrm{P}_{2} \mathrm{O}_{5}: \mathrm{K}_{2} \mathrm{O}: \mathrm{Zn}: \mathrm{B}: 11: 32: 13: 0.9: 0.24\right)\end{array}$ & 29.80 & 35.90 & 30.90 & 6.65 & 18.33 & 37.62 & 55.47 & 30.50 & 39.70 \\
\hline $\mathbf{T}_{\mathbf{5}}$ & $\begin{array}{l}75 \% \mathrm{RDF}+25 \% \mathrm{~N} \text { through sewage } \\
\text { sludge }\end{array}$ & 28.00 & 35.50 & 29.80 & 5.15 & 14.3 & 33.39 & 49.65 & 27.60 & 37.40 \\
\hline $\mathbf{T}_{6}$ & $\begin{array}{l}75 \% \mathrm{RDF}+25 \% \mathrm{~N} \text { through } \\
\text { vermicompost }\end{array}$ & 28.80 & 32.80 & 28.00 & 5.18 & 13.31 & 33.47 & 49.29 & 27.70 & 36.70 \\
\hline $\mathbf{T}_{7}$ & $75 \%$ RDF+ 25\% N through Sesbania & 29.00 & 34.00 & 30.20 & 5.57 & 14.26 & 33.8 & 49.67 & 28.40 & 35.50 \\
\hline \multicolumn{2}{|c|}{ SE $\mathbf{m} \pm$} & 0.65 & 1.36 & 1.47 & 0.33 & 1.12 & 0.88 & 0.77 & 0.73 & 0.44 \\
\hline \multicolumn{2}{|c|}{ CD $(P=0.05)$} & 2.00 & 4.19 & 4.52 & 1.02 & 3.46 & 2.71 & 2.37 & 2.24 & 1.34 \\
\hline
\end{tabular}


Table.3 Effect of nutrient management on yield and yield attribute of rice

\begin{tabular}{|c|c|c|c|c|c|c|c|c|}
\hline \multicolumn{2}{|r|}{ Treatments } & \multirow{2}{*}{$\begin{array}{c}\begin{array}{c}\text { Effective } \\
\text { tillers hill' }\end{array} \\
\mathbf{1}\end{array}$} & \multirow{2}{*}{$\begin{array}{c}\begin{array}{c}\text { Panicle } \\
\text { length } \\
\text { (cm) }\end{array} \\
18.3 \\
\end{array}$} & \multirow{2}{*}{$\begin{array}{c}\begin{array}{c}\text { Grains } \\
\text { panicle }^{-1}\end{array} \\
84\end{array}$} & \multirow{2}{*}{$\begin{array}{c}\begin{array}{c}\text { Test } \\
\text { weight } \\
(\mathbf{g})\end{array} \\
17.6\end{array}$} & \multirow{2}{*}{$\begin{array}{c}\begin{array}{c}\text { Grain } \\
\text { yield } \\
\left(\mathbf{q} \text { ha }^{-1}\right)\end{array} \\
30.9\end{array}$} & \multirow{2}{*}{$\begin{array}{c}\begin{array}{c}\text { Straw } \\
\text { yield } \\
\left(\mathbf{q} \text { ha }^{-1}\right)\end{array} \\
42.5\end{array}$} & \multirow{2}{*}{$\begin{array}{c}\begin{array}{c}\text { Harvest } \\
\text { index } \\
(\%)\end{array} \\
42.1\end{array}$} \\
\hline $\mathbf{T}_{1}$ & Control N, P, K $(00,00,00)$ & & & & & & & \\
\hline $\mathbf{T}_{2}$ & $100 \%$ RDF-NPK (120-60-60) & 9.58 & 20 & 133 & 21.1 & 49.2 & 64.6 & 43.2 \\
\hline $\mathbf{T}_{\mathbf{3}}$ & $\mathrm{RDF}+\mathrm{S}, \mathrm{Zn}, \mathrm{B}(40-05-1.5)$ & 11.8 & 21.4 & 137 & 21.5 & 50.3 & 68.2 & 42.4 \\
\hline $\mathbf{T}_{4}$ & $\begin{array}{l}\text { Customized fertilizer } \\
\left(\mathrm{N}: \mathrm{P}_{2} \mathrm{O}_{5}: \mathrm{K}_{2} \mathrm{O}: \mathrm{Zn}: \mathrm{B}: 11: 32: 13: 0.9: 0.24\right)\end{array}$ & 9.46 & 20.1 & 131 & 20.9 & 47.7 & 63.5 & 42.9 \\
\hline $\mathbf{T}_{5}$ & $\begin{array}{l}75 \% \mathrm{RDF}+25 \% \mathrm{~N} \text { through sewage } \\
\text { sludge }\end{array}$ & 8.93 & 19.9 & 126 & 20.3 & 41.9 & 71.8 & 37.2 \\
\hline $\mathbf{T}_{6}$ & $\begin{array}{l}75 \% \mathrm{RDF}+25 \% \mathrm{~N} \text { through } \\
\text { vermicompost }\end{array}$ & 8.5 & 20.1 & 132 & 20.5 & 45 & 58.3 & 43.3 \\
\hline $\mathbf{T}_{7}$ & $75 \%$ RDF+ $25 \%$ N through Sesbania & 8.88 & 20.5 & 131 & 20.6 & 45.6 & 57.8 & 44 \\
\hline \multicolumn{2}{|c|}{ SE $\mathbf{m} \pm$} & 0.6 & 0.19 & 1.71 & 0.14 & 2.03 & 3.48 & 1.7 \\
\hline \multicolumn{2}{|c|}{$\mathrm{CD}(\mathrm{P}=\mathbf{0 . 0 5})$} & 1.75 & 0.58 & 5.03 & 0.44 & 6.26 & 10.7 & NS \\
\hline
\end{tabular}


Table.4 Effect of nutrient management on gross return, net return and $\mathrm{B}: \mathrm{C}$ ratio of rice

\begin{tabular}{|c|c|c|c|c|c|}
\hline \multicolumn{2}{|r|}{ Treatments } & \multirow{2}{*}{ 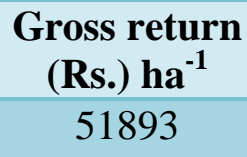 } & \multirow{2}{*}{$\begin{array}{c}\begin{array}{c}\text { Cost of cultivation } \\
\text { (Rs.) ha }\end{array} \\
21472\end{array}$} & \multirow{2}{*}{ 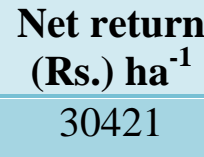 } & \multirow{2}{*}{$\begin{array}{c}\text { B:C ratio } \\
2.42\end{array}$} \\
\hline T1 & Control N, P, K $(00,00,00)$ & & & & \\
\hline $\mathbf{T 2}$ & $100 \%$ RDF-NPK (120-60-60) & 80413 & 27130 & 53283 & 2.96 \\
\hline $\mathbf{T 3}$ & $\mathrm{RDF}+\mathrm{S}, \mathrm{Zn}, \mathrm{B}(40-05-1.5)$ & 84003 & 29555 & 54448 & 2.84 \\
\hline $\mathbf{T 4}$ & $\begin{array}{l}\text { Customized fertilizer } \\
\left(\mathrm{N}: \mathrm{P}_{2} \mathrm{O}_{5}: \mathrm{K}_{2} \mathrm{O}: \mathrm{Zn}: \mathrm{B}: 11: 32: 13: 0.9: 0.24\right)\end{array}$ & 79420 & 31376 & 48044 & 2.53 \\
\hline T5 & $75 \% \mathrm{RDF}+25 \% \mathrm{~N}$ through sewage sludge & 73066 & 27121 & 45945 & 2.69 \\
\hline T6 & $75 \% \mathrm{RDF}+25 \% \mathrm{~N}$ through vermicompost & 74733 & 36611 & 38122 & 2.04 \\
\hline $\mathbf{T 7}$ & $75 \% \mathrm{RDF}+25 \% \mathrm{~N}$ through Sesbania & 75357 & 32716 & 42641 & 2.3 \\
\hline SE $\mathbf{m} \pm$ & & 2916.9 & - & 2916.9 & 0.1 \\
\hline \multicolumn{2}{|c|}{$\mathrm{CD}(\mathrm{P}=0.05)$} & 8987.9 & - & 8987.9 & 0.29 \\
\hline
\end{tabular}


Application of $100 \% \mathrm{RDF}+\mathrm{S}_{40} \mathrm{Zn}_{5} \mathrm{~B}_{1.5} \mathrm{~kg}$ $\mathrm{ha}^{-1}$ produced a maximum gross and net return and being at par with $100 \%$ RDF (T2) and customized fertilizer + urea (T4) produced significantly superior to other treatments. This could be ascribed to the higher grain and straw yield and moderate cultivation cost under T3 $\left(100 \% \mathrm{RDF}+\mathrm{S}_{40}\right.$ $\left.\mathrm{Zn}_{5} \mathrm{~B}_{1.5} \mathrm{~kg} \mathrm{ha}^{-1}\right)$. However, the application of $100 \%$ RDF (T2) due to its lower cost of cultivation and moderate gross return produce maximum benefit-cost ratio followed closely by T3 (100\% RDF $\left.+\mathrm{S}_{40} \mathrm{Zn}_{5} \mathrm{~B}_{1.5} \mathrm{~kg} \mathrm{ha}^{-1}\right)$ and T5 (75\% RDF+ 25\% $\mathrm{N}$ through sewage sludge). However, due to higher cost of vermicompost in treatment T6 $(75 \% \mathrm{RDF}+$ $25 \% \mathrm{~N}$ through vermicompost), it resulted in significantly low benefit-cost ratio, even less than control (T1). The increased net return and benefit: cost ratio in rice under integrated nutrient management were also reported by Das et al., (2003), Acharya et al., (2010) and Roy et al., (2013).

\section{References}

Abbas, M., Zahida, T.M., Uddin, R., Sajjid, I., Akhlaq, A., Moheyuddin, K., Salahuddin, J., Mari, A.H. and Panhwar, R.N. 2013. Effect of Zinc and Boron fertilizers application on some physicochemical attributes of five rice varieties grown in agro-ecosystem in Sindh, Pakistan. American-Eurasian Journal of Agricultural and Environmental Science. 13(4): 433-439.

Acharya, D. and Mondal, S. S.2010. Effect of integrated nutrient management on the growth, productivity and quality of crops in rice (Oryza sativa) - cabbage (Brassica oleracea) green gram (Vigna radiata) cropping system. Indian Journal of Agronomy. 55: 1, pp.1-5.

Babu, B. T. R. and Reddy, V.C.2000. Effect of nutrient sources on growth and yield of seeded rice (Oryza sativa). Crop
Research (Hisar). 19(2): 189-193.

Das, K., Medhi, D. N and Gupta, B. 2003. Application of crop residues in combination with chemical fertilizers for sustainable productivity in rice (Oryza sativa)-wheat (Triticum aestivum) system. Indian Journal of Agronomy. 48(1): 8-11.

Guo, Z.H., Li, H. S., Zhang, Y. Z., Huang, J. and Huang, C. Y.2002. Effects of phosphorous levels on hybrid rice growth and characteristics of phosphorus transportation. Chinese Journal of Rice Science. 16(2): 151156.

Hussaini, M. A., Mani, H. and Tanimu, B.2005. Effect of nitrogen, phosphorus and planting pattern on growth and yield of rice/sorghum intercrop, Journal of Sustainable Agriculture and the Environment. 7(1): 19-25.

Islam, M.R., Karim, M.R., Rasat, T.M. and Jahiruddin, M.1996. Growth and Yield of $\mathrm{BR} 11$ rice under different levels of $\mathrm{S}, \mathrm{Zn}$ and B fertility at two locations in Bangladesh. Thai Journal of Agricultural Science. 29: 37-42.

Jamil, M., Qasim, M., Umar, M. and Rehman, K.2004. Impact of organic wastes (sewage sludge) on the yield of Wheat (Triticum aestivum L.) in a calcareous soil. International Journal of Agriculture and Biology. 6(3): 465-467.

Jeyabal, A. and Kuppuswamy, G. 2001. Recycling of organic wastes for the production of vermicompost and its response in rice-legume cropping system and soil fertility. European Journal of Agronomy. 15:153-170.

Kumar, R., Kumar, R., Shivani and Kumar, S.2005. Effect of nitrogen and potassium levels on growth and yield of hybrid rice. Journal of Applied Biology.15(1): 31-34.

Ladha, J. K., Fischer, K. S., Hossain, M., Hobbs, P. R. and Hardy, B.2000. 
Improving the productivity and sustainability of the rice-wheat system of the Indo-Gangetic Plains: A synthesis of NARS-IRRI partnership research. Discussion paper 40. IRRI, Los Banos, Philippines.

Mahajan, A. and Gupta, R. D.2009.The ricewheat cropping system, integrated nutrient management (INM) in a sustainable rice-wheat cropping system. Springer Science. 109 -112.

Manzoor, Z., Awan, T.H., Zahid, M.A and Faiz, F.A.2006. Response of rice crop (super basmati) to different nitrogen levels. Journal of Animal and Plant Sciences. 16(1/2): 52-55.

Maqsood, Md., Babar, M. H. and Tayyad, Md.2005. Effect of nursery transplanting techniques and nitrogen levels on growth and yield of fine rice (basmati rice). Pakistan Journal of Agricultural. 42(3/4): 21-24.

Rahman, M.T., Jahiruddin, M., Ahiruddin, T. M., Humuan, M.R., Alam, M.J. and Khan, A.A. 2008. Effect of sulfur and zinc on growth, yield and nutrient uptake of boro rice (cv. BRRI Dhan 29). Journal of Soil and Nature. 2(3): 10-15. Roy, R., Singh, K., Singh, S. and Singh,
A.2013. Integrated nutrient management in rice (Oryza sativa). Indian Journal of Agronomy. 58(2): 203-207.

Singh, S.P., Bhardawaj, A.K., Singh, Y., Singh, R.K., Chaudhary, D.C. and Saxena, A.2000. Integrated nutrient management in rice (Oryza sativa L.) wheat (Triticum aestivum L.) cropping system for sustainable production. Extended Summaries Vol. 1: 2nd International Agronomy Congress, Nov. 26-30, New Delhi. pp. 60-61.

Sudhakar, P. C., Singh, J. P., Singh, Y. and Singh, R.2006. Effect of graded fertility levels and silicon sources on crop yield, uptake and nutrient use efficiency in rice (Oryza sativa). Indian Journal of Agronomy. 51(3): 186-188.

Tejasarwana, R.1991. The effect of Zn, N and $P$ fertilizers on the yield of low land rice. Media-Panelition-Sukamandi (Indonesia). 10: 17-20.

Watanabe, K., Niino, T., Murayama, T. and Nanzyo, M. 2007. Promotive effect of pre-transplanting phosphorus application on the early growth of rice. Japanese Journal of Crop Science. 76(2): 181-188.

\section{How to cite this article:}

Papia Biswas, Jitendra Singh Bohra and Nitesh Kumar. 2020. Effect of Nutrient Management on Growth, Yield and Yield Attributes of Rice (Oryza sativa L.). Int.J.Curr.Microbiol.App.Sci. 9(03): 3136-3146. doi: https://doi.org/10.20546/ijcmas.2020.903.359 